\title{
Planning of public open spaces with digital tools. The example of the WAY CyberParks
}

Tiago Duarte [0000-0002-6 /67-1399], Universidade Lusófona, Interdisciplinary Research Centre for Education and Development - CeiED, Lisboa, Portugal. tiagoaduarte@gmail.com

Diogo Mateus [0000-000 I-7862-7I 78], Universidade Lusófona, CeiED, Lisboa, Portugal. dmateus@ulusofona.pt

\begin{abstract}
The aim of this chapter is to discuss how digital technology can assist public open spaces' planning processes. It is centred on the opportunities that digital technology offers to aid spatial planning, by introducing the monitoring tool WAY CyberParks, developed and tested within the CyberParks Project. This digital tool intends to increase information and knowledge about places in order to create more inclusive public spaces that correspond to the needs of their users. The digital tool, developed to monitor how people use public spaces and as an exchange interface between users and planners, increases the understanding of users' needs and preferences. The challenge is to attract users to engage with the app during their visit to public spaces and define the number of users required to obtain a representative sample. One of the main objectives of this digital tool is to allow strong public participation, therefore users' opinions should be representative. As a result, WAY CyberParks intends to be $a$ tool to be used by planners in the co-creation of public spaces. The analysis of the tests of WAY CyberParks in Lisbon serves to demonstrate the features of this tool and the type of data gathered. This chapter makes an analysis of the strengths and weaknesses of this tool, and the advantages of using digital tools in the processes of planning and co-creating public open spaces.
\end{abstract}

Keywords - Public open spaces, WAY CyberParks, digital public participation, co-creation of public open spaces, urban planning 


\section{INTRODUCTION}

This chapter analyses how digital tools can be used to increase public participation in public space planning. It is not a comparison between tools and their usability, but rather a discussion about some results obtained in the scope of the ongoing research work for the doctoral thesis "The importance of digital tools in the co-creation of public open space - the case of WAY CyberParks," developed by Tiago Duarte. The research aims above all to critically analyse the potential of a specific tool, WAY CyberParks. This tool was developed under the COST Action TU I 306 CyberParks, which fostered knowledge about the relationships between people, ICTs and public spaces, supported by strategies aimed to improve their usability and attractiveness. CyberParks was established as an interdisciplinary research platform that included the collaboration of different working groups to understand the relationship between ICTs and the production and use of public open spaces as well as their relevance to urban development. The Way CyberParks is developed by DeustoTech-Mobility in Bilbao and tries to respond to the needs of researchers and planners to collect the "feelings" and contributions of people in creating better public spaces. Throughout this chapter, a brief description of WAY CyberParks will be given, in order to demonstrate its potential. The results obtained in a workshop carried out in the Mouraria neighbourhood in Lisbon are considered and analysed. Finally, conclusions about the advantages of the use of this digital tool in the process of co-creating public spaces will be presented.

With the opportunities created by digital tools, it is important to understand if they can replace the traditional methods of public participation. Bearing in mind that public spaces play an important role in the interpersonal relations, for friendship and sharing of knowledge and experience (Gehl, 2017), it is useful to rethink urban planning in terms of a more participatory and inclusive perspective through digital tools. From this perspective, the production of public spaces should encourage and enable people to actively participate in the planning process, from the development of a concept to an action plan or to the maintenance of the place. The "New Charter of Athens", revised in 2003 (Conselho Europeu de Urbanistas, 2003), refers specifically to the use of new information and communication technologies (ICTs), arguing that cities should be physically and virtually connected. Furthermore, the Charter argues that technological developments in communication, information and transportation should benefit citizens and the city as a whole. Currently, our society is organised around technological developments, generalised internet access being an example. The new means of communication have greatly changed the quantity, quality, and speed of information transmission. Associated with a general scarcity of basic information in urban planning, the new digital research forms enable a better understanding of the territory (Frota, 2015). 


\section{THE WAY CYBERPARKS DIGITAL TOOL}

Nowadays it is quite common to see people using digital communication devices, such as smartphones and tablets, in public spaces. Among other things, these devices enable them to send and receive calls and emails, to take pictures and make movies, for entertainment and leisure (reading or play) and socialize (interactions). Our day-to-day life is endowed with instruments that allow us to access quickly, and in a relatively easy manner, information that would otherwise take more time to obtain. It is through the use of these new tools that a challenge arises for the different experts interested in the production of urban spaces, namely, to increase the knowledge about how to promote these new forms of communication as tools to support decision making in planning, producing and maintaining public spaces (Smaniotto et al., 20I5). These new forms of interaction can facilitate the collection of data about public space users, i.e. data to identify people's opinions and needs regarding such spaces, contributing to the adoption of creative solutions and/or forms for maintenance of spaces that meet people's needs. In order to follow this path, it is necessary to equip the digital tools to carry out this task meaningfully. Having better knowledge of the spatial needs/preferences of users can aid the finding of solutions that are capable to increasing the quality and usage of public spaces.

It is also important to compare different research methods (traditional and digital) and evaluate their merits and drawbacks, i.e. paper- or web-based questionnaires or interviews. The possibility of collecting data faster, as well as greater independence of the respondents, with more privacy, without anyone conditioning opinions, are great advantages. Also, smartphones are becoming user-friendlier, so that people can be approached to share ideas and opinions about urban space in entertaining and/or informal ways. In addition, given the current challenges posed to the urban society, i.e. time scarcity for leisure, social exclusion of specific groups (e.g. seniors, immigrants, etc.) to mention only a few, it is essential to create spaces that not only bring more people outdoors - to an open and healthier environment, but also that such contexts be more inclusive and fit users' needs better, for example, countering people's tendency to stay indoors, often connected to a virtual world but not to the real city. Summing up, we must strive to find answers to the question, as put by Thomas (2013) how "can we capitalize on our newly discovered love for wired-life to encourage more people to go outside and use the city?"

The Digital Tool WAY CyberParks allows researchers to inquire into the perceptions of public spaces. It consists of three main elements: a mobile application for smartphones (app), a set of web services, and the cloud. This tool is part of the broader research programme WAY (Where Are You?) of DeustoTech-Mobility (Bilbao) which proposes to develop mobile applications to continuously support people's location and orientation, regardless of the environment. WAY CyberParks 
was tested in several countries associated with the CyberParks Project. In Lisbon, this tool was applied in different contexts in the Quinta das Conchas Park, in Príncipe Real Square and in the Mouraria neighbourhood. Studying these places in Lisbon is part of the above-mentioned doctoral thesis. This chapter focuses on the results obtained in Mouraria.

The application, available in IOS e Android versions, offers its users some services: obtaining information about a space, previously loaded and made available by points /places of interest; visualizing their own position and the location of the points of interest by real time map navigation. This latter feature is common to many applications, but in WAY CyberParks it is enhanced by the possibility of including quizzes, whit questions arising in specific locations. The tool also provides a suggestion box, where a user can freely upload an audio, image or video file and/or make text commentary, making it possible to collect geolocated information, opinions and perceptions. On the Android platform, a virtual reality service is available, and it is possible to include three-dimensional virtualised elements, allowing the visualization of equipment proposals to be placed in the public space, as well as gather opinions about them. It should be noted that the application can be used online or offline; the latter involves the need to upload the information collected to the web platform when the application is connected. In the offline mode, some features have limited functionality.

The web platform enables different types of information generated by the app to be analysed, such as the real-time position of users and their routes, also in terms of their duration and distance, the weather conditions, as well as users' suggestions and responses to questionnaires. The transmission of information between these two elements (mobile application and web platform) is performed automatically through the cloud. The potential of the system results from the combination of the mobile application (app) - more directed to the user - and the web platform that hosts the database which allows data to be collected, stored and read, as well as information - more targeted at the investigator/planner - to be uploaded. The web platform, where the collected data is stored, enables different types of analysis global analysis and/or by type of information, such as by user profiles, by date, time or period of the day, weather conditions, as well as the analysis of suggestions and answers obtained. In the case of users, as they fill out a profile form when they first access the application, the analysis can be done by age group, gender, schooling level, training area, profession, place of employment and residence.

The WAY CyberParks app enables planers to obtain the opinion of different users on specific issues related to a public space. The advantage of an application of this nature is related to ( $I$ ) real-time data gathering, (2) maintaining an updated database, (3) capturing the different users' activities in the same space, and (4) recording their opinion, via geolocated texts, videos or images. The analysis of the collected information through the mobile application enables planners to obtain better 
knowledge about the use of the space, as well as users' opinions and suggestions regarding said space. The quality of the collected data contributes to enhance scientific knowledge and to improve methodologies of participatory planning. At the same time, it helps to enrich planning practices and policy making - now more grounded on people's interests and needs.

\section{WAY CYBERPARKS WORKSHOP - AN EXPERIENCE IN MOURARIA}

On June 15, 2017, as part of the European Researchers' Night and in the scope of activities prior to the event, the workshop entitled "WAY CyberParks app - Science in Lisbon", organized jointly with the CyberParks Portuguese team, took place in the Mouraria neighbourhood. The main objective of the workshop was to test the WAY CyberParks app, using a new location. The results obtained were processed, analysed and presented at the event. The workshop was attended by 20 participants who, in groups, used the app. Prior the workshop, some preparation tasks had to be carried out, i.e. the delimitation of the area to be studied, defining and locating questions that we would like to have answered, as well as adding the places of interest. The placement of this information was based on site visits for its analysis.

The workshop started with a short presentation of WAY CyberParks, and its purpose, as well as of the CyberParks Project. The participants were informed about the area covered by the workshop / app test, which did not correspond to the entire area of Mouraria, due to the limited time available. The participants were told to use the neighbourhood in the same way they would normally do, and to extensively make use of the suggestion box. The purpose of this workshop was to test the WAY CyberParks app and its functionalities and to take advantage of the opportunity to participate in the European Researchers' Night, in order to encourage greater dissemination of the project and of the digital tool. The data collected are as follows: I) Track of each user's route(s), 2) Information uploaded in the suggestion box, 3) Answers to a questionnaire on the space visited, and 4) Paper questionnaire on the applicability and user-friendliness of WAY CyberParks.

In Lisbon, this kind of workshop had been used previously, also within the framework of the activities related to the European Researchers' Night, in Quinta das Conchas Park. Duarte and Mateus (2017) address the results of the app test in Quinta das Conchas. Backed by the experiences and the results obtained, it was possible to establish again more aspects to be improved in the digital tool. Among them, there were some related to the app features, as some small shortcomings had been detected, like for example the way notifications for the questions popped up, and the type of information placed in the Pls. Another issue was the number of questions in the questionnaire, which was considered too long.

This type of research tool needs continuous upgrades, in order to adapt it to the objectives or requirements. In the case of WAY CyberParks, this has been the subject of improvements based on different field tests, such as in Fòrum de les 
Cultures and Carrer d'Enric Granados in Barcelona in 2014 (Duarte, 20I4), where some flaws were identified. Only with such tests was it possible to bring the app closer to the conditions necessary for effective use and for meaningful data collection.

\section{The routes of each user}

Through the use of the GPS receiver incorporated in a smartphone, WAY CyberParks is able to record the route of users (tracking) in a public space. This function increases understanding of how people use the space, which routes they take, the distance covered and its duration. Fig. I shows a screenshot of the web-service of WAY CyberParks showing different users and their routes during the workshop.

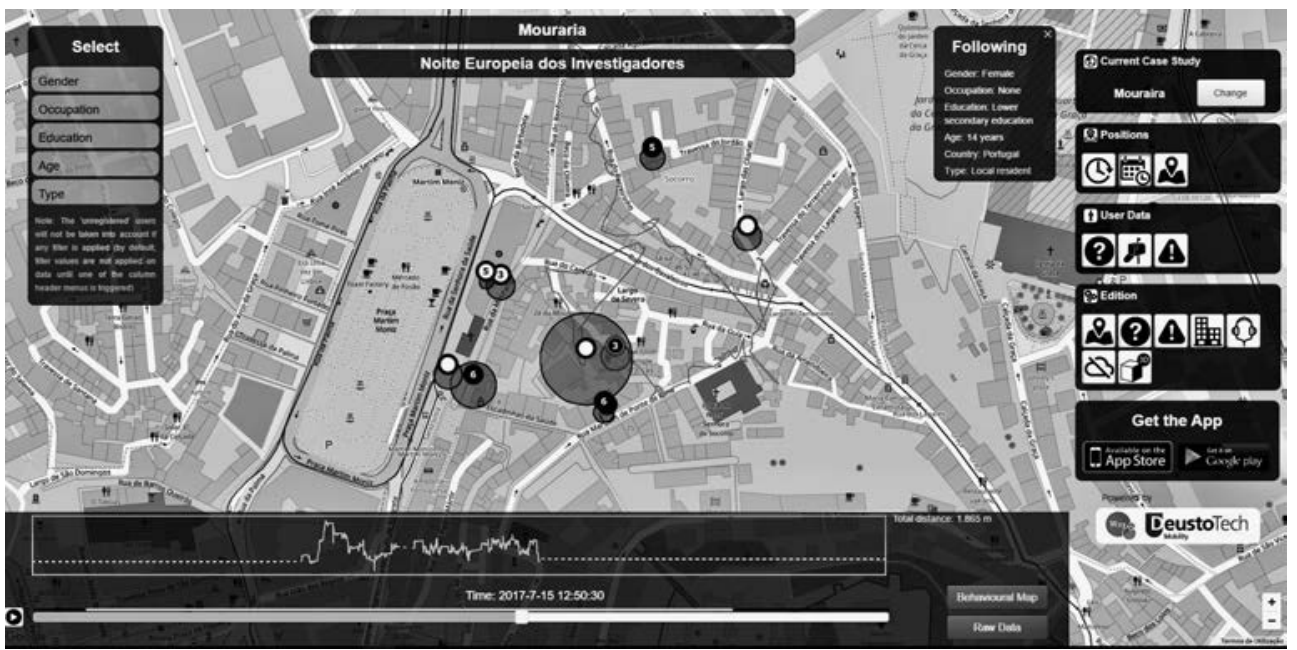

Fig. I: Screenshot of WAY CyberParks, showing users' tracks and distances covered. Source: http://services.cyberparksproject.eu.

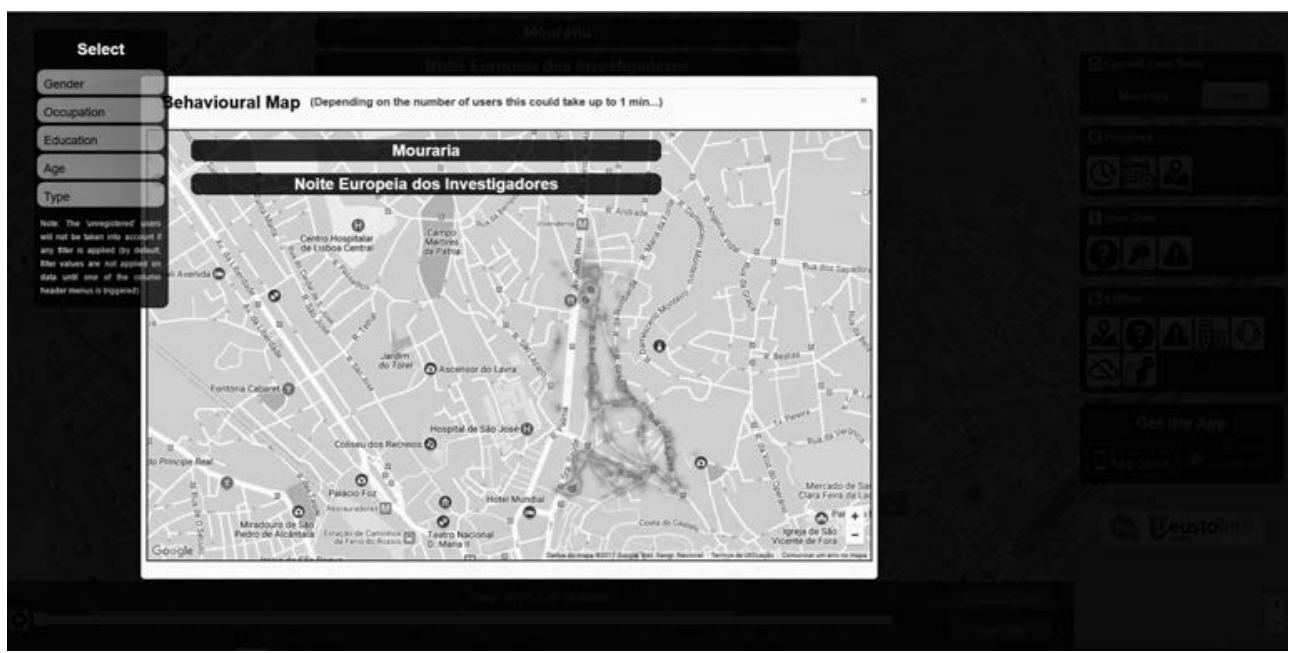

Fig. 2: The behavioural map. Source: http://services.cyberparks-project.eu 
On the website, it is possible to see all routes, duration and distances of the journeys of the different users. Since they were included in a workshop, the time limit, distances as well as the range of action turned out to be very similar. The behavioural map (Fig. 2) indicates the places with the longest stay.

However, even with these small constraints, an analysis of the obtained results - to verify the potential of the application - could be performed, as planned. Regarding the features, the findings do not reveal divergences with the outlined objectives, but they reinforce the great possibility of analysing different routes without the need for users to take specific care. It is only necessary for the app to be on.

\section{Information placed in the WAY CyberParks suggestion box}

At the Workshop, the participants were encouraged to use this functionality in order to provide suggestions as well as indicate the strengths and weaknesses observed. In total, 6 I suggestions were sent, a figure that was very relevant to the number of participants, and these allowed us to gauge the app's functionality. The sound feature was used only once, and only three videos were uploaded. Sending suggestions was done mostly through text and image, and the use of text and image in the same suggestion was the most commonly used option. Fig. 3 depicts an example of a suggestion made using text and image.

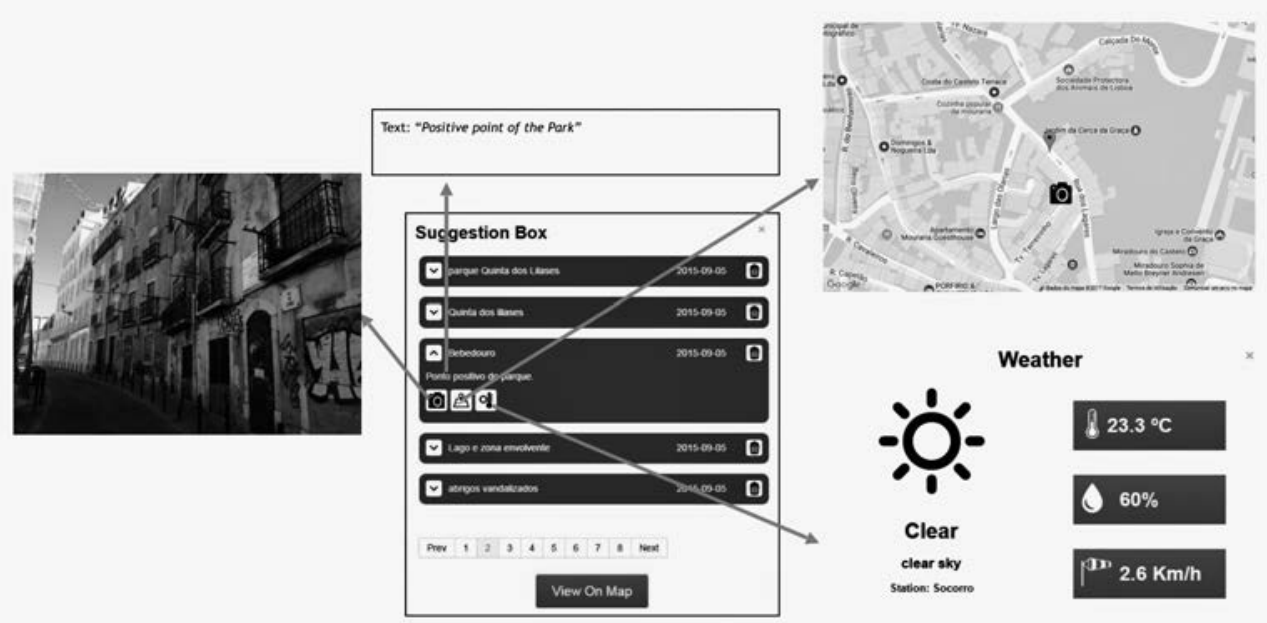

Fig. 3: Suggestion box elements. Source http://services.cyberparks-project.eu

WAY CyberParks follows the trend of geolocation entrenched in mobile applications. For all suggestions sent to the web services, it provides georeferenced data as well as the weather conditions at the time of submission. This functionality has enormous potential, since it allows gathering different opinions, providing their exact location and weather conditions without forcing the researcher to be present in the space. The type of suggestions may be as diverse as possible. In the case of this 
workshop, the participants were asked to send suggestions related to the app, as well as identify positive and negative aspects in the urban space. Regardless of the goals, the app is so assembled that it enables getting answers. This is undoubtedly an important feature of WAY CyberParks: being dynamic in order to be able to gather different types of information according to the research needs. This kind of information can be also obtained by traditional research methods, i.e. using interviews and paper-based questionnaires, but the app allows, first, a great number of entries, and second, more relevant, it facilitates the analysis of data. It also allows a more effective response to specific data privacy issues, since the data collected is not personalized, while in traditional research method the respondent is inevitably faced by an interviewer.

\section{WAY CyberParks' questionnaire about the visited space}

Another example of a dynamic component of WAY CyberParks is related to the possibility of asking questions about the urban spaces, questions that are automatically displayed when the user is within range of the previously defined. This functionality is an asset in collecting opinions on public spaces and can be a fast and effective way to interact with users. In the Mouraria workshop, the set of locations and the related questions to be put to the participants were defined in a previous site visit. These questions are mostly related to the characteristics of and personal opinion about the urban space. The questions that were asked and that were intended to be answered can be found below.

\begin{tabular}{|l|l|l|}
\hline Question & Location & Answer Options \\
\hline Did you already know this area? & $\begin{array}{l}\text { Intendente Square / Benformoso } \\
\text { Street (beginning of the course) }\end{array}$ & Yes/No \\
\hline $\begin{array}{l}\text { If your answer is 'yes': do you } \\
\text { come here often? If not, why } \\
\text { not come here before? }\end{array}$ & $\begin{array}{l}\text { Intendente Square / Benformoso } \\
\text { Street (beginning of the course) }\end{array}$ & Open answer \\
\hline $\begin{array}{l}\text { Please state why you chose } \\
\text { this route? }\end{array}$ & Olarias Staircase & $\begin{array}{l}\text { Already Known/ Curiosity } \\
\text { /Transit / Other / I don't know }\end{array}$ \\
\hline $\begin{array}{l}\text { What is your opinion about } \\
\text { this place? }\end{array}$ & Mural in Benformoso Street & $\begin{array}{l}\text { Rate out of I to 5, where I is uninteresting } \\
\text { and } 5 \text { is very interesting }\end{array}$ \\
\hline $\begin{array}{l}\text { Do you consider the noise level } \\
\text { here uncomfortable? }\end{array}$ & Olarias square & $\begin{array}{l}\text { Rate from I to 5, where I is a bit annoying } \\
\text { and } 5 \text { very annoying }\end{array}$ \\
\hline $\begin{array}{l}\text { What do you think of this } \\
\text { intervention in urban space? }\end{array}$ & $\begin{array}{l}\text { Corner of the Travessa da Paz } \\
\text { (urban furniture - table and benches) }\end{array}$ & $\begin{array}{l}\text { Rate out of I to 5, where I is uninteresting } \\
\text { and } 5 \text { is very interesting }\end{array}$ \\
\hline $\begin{array}{l}\text { How satisfied are you with the } \\
\text { sidewalk? }\end{array}$ & Agostinho de Carvalho Street & $\begin{array}{l}\text { Rate I to } 5 \text {, where I is unsatisfied } \\
\text { and } 5 \text { is very satisfied }\end{array}$ \\
\hline $\begin{array}{l}\text { What is your opinion about } \\
\text { Tuk Tuks in Mouraria? }\end{array}$ & Santo André Street & $\begin{array}{l}\text { Rate out of I to 5, where I is uninteresting } \\
\text { and } 5 \text { is very interesting }\end{array}$ \\
\hline $\begin{array}{l}\text { How do you rate the interest } \\
\text { of this place? }\end{array}$ & Square next to the Três Engenhos-Alley & $\begin{array}{l}\text { Rate out of I to 5, where I is uninteresting } \\
\text { and } 5 \text { is very interesting }\end{array}$ \\
\hline $\begin{array}{l}\text { Do you think there should be } \\
\text { more playground equipment? }\end{array}$ & Playground on the Capelão Street & \begin{tabular}{l} 
Open answer \\
\hline
\end{tabular} \\
\hline
\end{tabular}




\begin{tabular}{|l|l|l|}
\hline Question & Location & Answer Options \\
\hline $\begin{array}{l}\text { What do you think about } \\
\text { the contrast between } \\
\text { the new and the old? }\end{array}$ & $\begin{array}{l}\text { Crossing of Capelão Street } \\
\text { and Mouraria Street }\end{array}$ & $\begin{array}{l}\text { Rate out of I to 5, where I is uninteresting } \\
\text { and } 5 \text { is very interesting }\end{array}$ \\
\hline $\begin{array}{l}\text { Which are the } 5 \text { highlights of } \\
\text { great interest in your route? }\end{array}$ & Mouraria Street (end of the route) & Open answer \\
\hline $\begin{array}{l}\text { Which are the } 5 \text { highlights of } \\
\text { little interest in your route? }\end{array}$ & Mouraria Street (end of the route) & Open answer \\
\hline
\end{tabular}

Table I - List of questions placed in the WAY CyberParks app for the Mouraria Workshop

The content of the questions was very diverse, as well as the possibilities for answering them. For some questions, the opinions could be valued on a graded scale from I to 5, others were open, for sending texts or simply typing yes or no. The app enables users to ask questions through existing forms, and the way the answers are to be delivered has to be defined. For these questions it is also possible to define the range of action that meets the planned goals. Only within this radius do the questions pop up to be answered by the user. Fig. 4 shows an example of the results obtained in one of the questions put in Mouraria. It is the question launched at the corner of Travessa da Paz, and it asked participants to give their opinion about pieces of urban furniture recently placed there. The features of Travessa da Paz, with the sidewalk and the street furniture, are shown in Fig. 5. The graphic is generated automatically by the web service. Through it, it is also possible to filter the answers using different parameters such as age, gender, and/or neighbourhood of residence, for example.

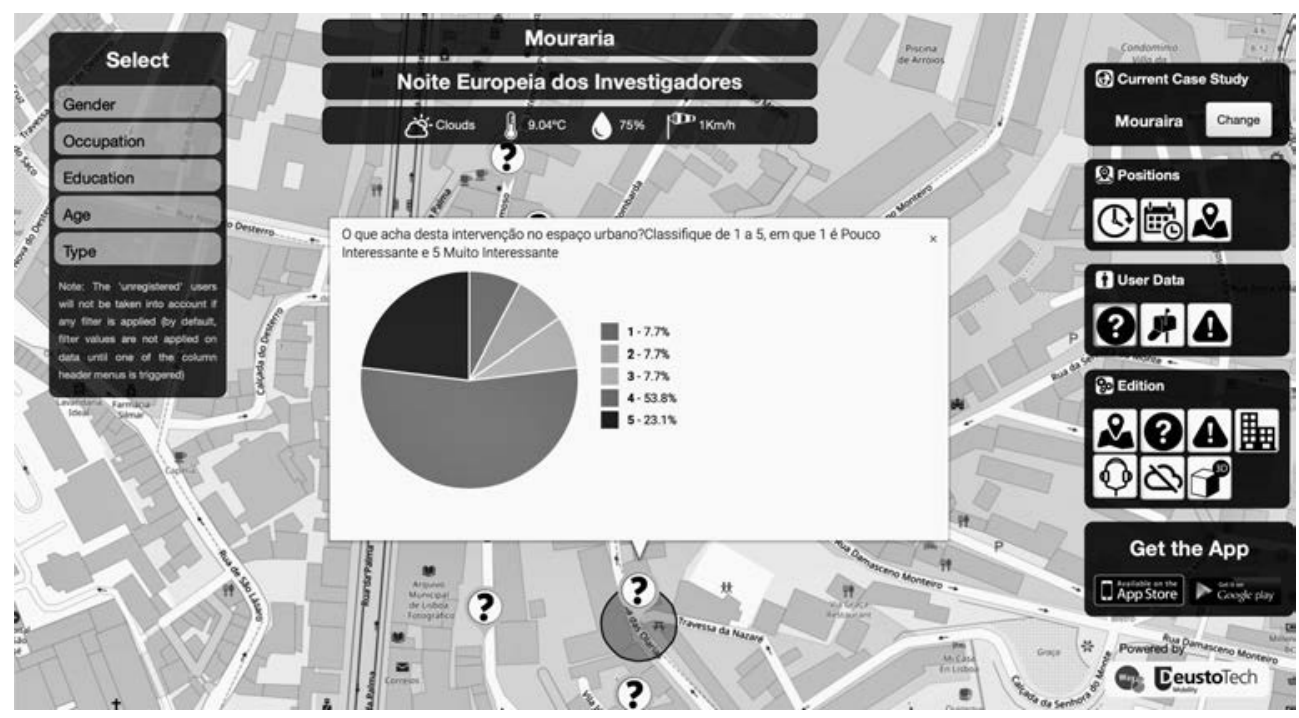

Fig. 4: Answers obtained to the question "What do you think of this intervention in the urban space?" placed at the corner of Travessa da Paz. Source: http://services.cyberparks-project.eu 


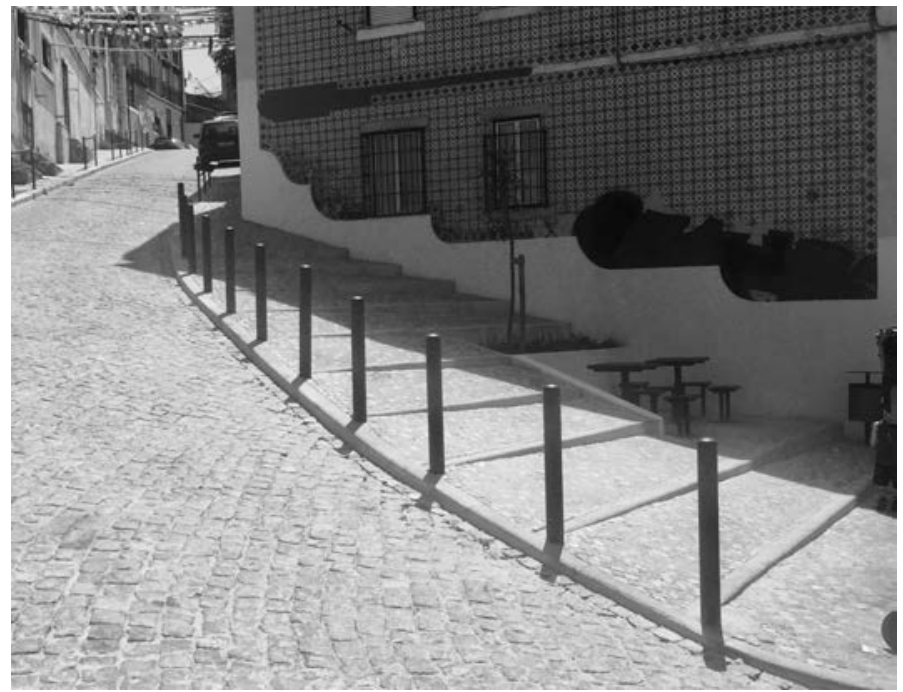

Fig. 5: Corner of Travessa da Paz. Source: Tiago Duarte.

Selecting the question about Travessa da Paz is linked to a recent urban rehabilitation project by the city council in this street: $A$ set of tables and benches were installed on the broad sidewalk to invite people to prolong their stay in the area. The majority of participants considered this intervention "interesting" and "very interesting", evidencing the positive changes in this place. This question also demonstrated that such a tool can bring enormous advantages over traditional methods, as in paper-based questionnaires it would be difficult to ask such a specific question.

\section{Paper-based questionnaire on the tool WAY CyberParks}

Taking advantage of the workshop, a paper-based questionnaire was distributed to the participants in order to get their feedback about the user-friendliness of the app. The questionnaire was handed to the participants at the end of the workshop.

The analysis of the app's functionalities shows that the participants appreciated the questions, stating that they were simple and objective, and that they enable the assessment of the places they reached along of their way. On the other hand, when asked which further questions should have been asked, since in some cases the questions are very general, there were statements calling for more place-specific questions. It should be noted that this workshop aimed primarily to test the app in a real context, therefore, the main concern was not to go deep into the quality issues of public spaces, but rather to use simpler questions to evaluate the effectiveness of the app's functionalities. When asked about suggestions for improving the app (question 4), the respondents provided diverse answers, but some included the request to increase the number of points of interest, improve the speed in accessing the smartphone camera, better adapt the icons to the questions, provide easier access to the points of interest and supply the app map with a guidance 
feature. It was also mentioned that the process of submitting suggestions could be made easier and the app's own image improved, making it easier to understand the functionalities behind the buttons.

The participants were also asked whether they had found something new in Mouraria through the use of WAY CyberParks. The answers were positive, as through the app it was possible to discover new streets and places. There were also some participants who did not know the neighbourhood, mentioning that the app was a guide for the discovery tour. In general, with these answers one of the workshop objectives was met: to support visitors in getting to know the place better. This is one of the major differences from traditional methods, as with them it would be almost impossible for people to discover something new. With such a digital tool, people enjoy the possibility of discovering the urban space autonomously, and, should this be the goal, there may be cases where it can be done alone.

\section{CONCLUSIONS}

The use of digital tools in the analysis and assessment of public open spaces allows for a new kind of approach to placemaking, facilitating information gathering, making the process faster and more effective, and, depending on the case, more accurate when compared to more traditional research methods (paper-based questionnaires, interviews, etc.). However, just as all research tools, irrespective of whether they are more traditional or more innovative, digital tools have also limitations. For example, without internet connection, most features of the WAY CyberParks app are limited in their functionalities. Since WAY CyberParks is an interactive tool, its usage can play a relevant role not only in the creation of new public spaces but also in the maintenance and improvement of existing places.

Through the features of the app it is possible to develop new approaches to public participation in the process of producing public spaces, with greater involvement from citizens, and consequently with a greater probability of success in the planning process. Certainly, there are still some shortcomings in the tools, as detected in the workshop in Mouraria, but these do not diminish its potential in comparison to traditional research methods. Such digital tools enable researcher and professionals to think about digital public participation, where all actors can become more involved in co-creation processes, and consequently take on more responsibilities in defining the public space more suited to the needs of all.

From the discussed case study and in view of the analysis of the potentialities of WAY CyberParks, it can be stated that the workshop allowed a better understanding of the advantages of technology compared to more traditional research tools. Due to the positive effects shown, such as the ability to be easily adapted to different needs and environments, and respond to different issues, making data collection faster and smarter, technology can be an easy and economical research method. 
The WAY Cyberparks app allows for the accurate and continuous monitoring of individuals, and the data collected are especially rich and meaningful. The next steps are to expand and increase the use of the app in further case studies. This will provide the basis for assessing the relevance of digital tools in understanding the relationship between public spaces and users. Further opportunities will be identified, in order to explore the tool's potential for contributing to the improvement of public spaces by responding to community needs and taking advantage of participatory methods, such as co-creation.

\section{ACKNOWLEDGEMENTS}

This work has been supported by the COST Action TUI 306 CyberParks: Fostering knowledge about the relationship between Information and Communication Technologies and Public Spaces, and is part of the ongoing research for the $\mathrm{PhD}$ Thesis of Tiago Duarte, "The importance of new technologies in the study of public spaces - The pertinence of using mobile applications. Case study WAY CyberParks app".

\section{REFERENCES}

Conselho Europeu de Urbanistas (2003). A Nova Carta de Antenas 2003 - A Visão do Conselho Europeu de Urbanistas sobre as Cidades do séc. XXI. CEU, Lisboa, Novembro de 2003. Available at https://paginas.fe.up.pt/construcao2004/c2004/docs/SAT_02_carta atenas.pdf [Accessed on 7/0 1/2019].

Duarte, T. (2014). The Importance of New Technologies in the Study of Public Spaces - Scientific Report resulting of STSM made in Barcelona (Nov 19th - Nov 28th, 2014). Available at http:// cyberparks-project.eu/stsm/importance-new-technologies-study-public-spaces. [Accessed on 2/01/2019].

Duarte, T., Mateus, D. (2019). O espaço público aberto e as ferramentas digitais. Um estudo com a aplicação WAY CyberParks. In: Menezes, M. \& Smaniotto Costa, C. (Eds.) Neighbourhood \& City Between digital and analogue perspectives. Lisbon: Edições Universitárias Lusófonas: 365-374.

Duarte, T., Mateus, D. (2017). The Contribution of ICT in Planning of Public Open Spaces - Reflections on the City of Lisbon. In: Antoine Zammit and Therese Kenna (Eds.). Enhancing Places through Technology. Proceedings from the ICiTy conference. Valletta, Malta I8-I9 April, 20I6. Lisbon: Edições Universitárias Lusófonas: 4I-56.

Frota, N. (20I5). Introdução do uso de ferramentas de geoprocessamento no ensino do Planeamento Urbano e Projeto Urbanístico. In: Anais do VII Encontro de Tecnologia de Informação e Comunicação na Construção - TIC20I5 [ANTAC e Blucher Engineering Proceedings]. Porto Alegre: ANTAC; São Paulo: Blucher: 630-640.

Gehl, J. (2017). A Vida entre os Edifícios (I. ${ }^{a}$ Edição). Lisboa: Livraria Tigre de Papel, Cicloficina dos Anjos.

Smaniotto Costa, C.; Menezes, M.; Mateus, D.; Bahillo Martínez, A. (20I5). Podem as tecnologias da informação e comunicação contribuírem para capacitar o conhecimento das práticas e necessidades de uso de parques urbanos? In I. C. da Silva, M. Pignatelli, \& S. de M. Viegas (Eds.), Anais do XII Congresso Luso-Afro-Brasileiro de Ciências Sociais - XII CONLAB, February I-5th, Lisbon. Lisboa, p. 7705-77I 3.

Thomas, S. (2014) - Cyberparks will be intelligent spaces embedded with sensors and computers. Available at http://theconversation.com/cyberparks-will-be-intelligent-spaces-embedded-with-sensorsand-computers-26837. [Accessed on 2/01/2019]. 


\section{NOTES ON CONTRIBUTORS}

Inês ALMEIDA holds a licentiate degree in Clinical Psychology and Counselling and a master's degree in Social and Solidarity Economics. Inês has collaborated in several institutions, carrying out clinical and research work. Presently, she is a PhD student in Urban Planning at Lusófona University and has been working in the C3Places research project at the interdisciplinary Research Centre for Education and Development - CeiED, at the same institution.

Manoel Rodrigues ALVES. Architect, professor of urban design and theory of architecture and urbanism: IAU-USP. Graduate FAU-MACKENZIE, Master of Science in architecture studies-MIT, PhD FAU-USP. Invited Professor: ETSA, Universidad de Seville; FADU, Universidad Nacional del Litoral. LEAUC Research Group, focus on public space and spaces of public domain, socio-spatial practices; contemporary city, production and processes; high-rise living and verticalization processes. Ongoing research: Highrise Living and the Inclusive City (joint binational French-Brazilian project, USP and Université Lyon 2); Public Space and Contemporary City: Imaginaries and liminarities.

Jenny BERGSTRÖM, MFA, is a research associate in design at the Department of Design. She teaches Critical and Creative Thinking and Creative Design Processes. Her design practice focuses on hands-on material explorations as well as the relation between design, perception and experience of products and services. Since graduating with an MFA, Jenny has been combining work in both corporate and academic contexts with art projects and teaching commissions.

Igor BIZJAK (PhD) graduated in 1987 with the thesis "Computer variants of the program for a set of industrial facilities in a specific location". He finished his doctorate in 2014 with the thesis "Web model for public participation in the spatialplanning procedures". He is currently working at the UIRS as director. His scope of work includes the production of program-specific add-ons for GIS presentations and analyses, spatial data processing and creation of Web platforms in the field of urban planning.

Dick BOTTELDOOREN is a full professor at Ghent University, where he teaches courses on acoustics, urban noise, and computational methods, and leads acoustics research. His personal research focuses on environmental noise and includes urban sound planning, sound perception and policy support. His work has been reported in over 150 journal publications and hundreds of conference contributions. He has worked as advisor for noise and health in national and international organisations. 
Jonas BYLUND has been a member of the JPI Urban Europe Management Board since 20I3. His main responsibility is science-policy communication and development of research and innovation calls with affiliated funding agencies as well as strategic transnational initiatives. Since 2013 he has also been employed at the Swedish Centre for Innovation and Quality in the Built Environment. He is trained in human geography and social anthropology, with a specific research focus on the knowledge practices in planning and environmental sciences. He is an experienced lecturer in urban and regional planning, with a particular focus on epistemology and ontology in social sciences. He is also a consultant at Urbanalys.

Bert DE COENSEL is a part-time associate Professor in computational psychoacoustics at Ghent University, and adjunct research fellow at Griffith University. He holds an MSc degree (2002) and a PhD degree (2007), both in Engineering Physics, from Ghent University. He has been a visiting researcher at Stockholm University, UC Berkeley, Griffith University and the University of Cergy-Pontoise. He is co-author of about I 50 publications in journals and conference proceedings. In 20I5, he co-founded the spin-off company ASAsense.

Toon DE PESSEMIER received his MSc degree in computer science engineering at Ghent University in 2006. In 20 I3, he obtained a PhD on his research "Improved online services by personalized recommendations and optimal quality of experience parameters". In 2015, he obtained a post-doc scholarship for his research "Design and validation of innovative techniques to assist people in the decision making process by analyzing data of user behavior and contextual features". Since 2018, he has been part-time assistant Professor, teaching Recommender Systems.

Tiago DUARTE graduated in environmental engineering from Universidade Lusófona, where he is a PhD candidate in Urbanism, developing the thesis titled "The importance of new technologies in the study of public spaces - The pertinence of using mobile applications. Case study the WAY CyberParks app". He is a researcher on territorial studies at CeiED - Interdisciplinary Research Centre for Education and Development and was a member of the CyberParks Project (Action COST TU 1306). He is also project coordinator at Perspectiva, where he develops environmental plans and studies.

Kristina EK $(\mathrm{PhD})$ is an associate professor in economics at the Department of Business Administration, Social Sciences and Technology. Kristina has extensive experience in research on the interface between behavioural, environmental and energy economics, and she has been studying motives for and barriers to individuals' willingness to support renewable energy projects and to buy "green" products such as renewable electricity. 
Björn EKELUND (PhD) is a senior lecturer in architecture at the Department of Civil, Environmental and Natural Resources Engineering. Björn has research experience on both participatory design processes as well as the design history and future of infrastructure, with a specific interest in facilities for energy production and distribution. His work has been published both as design artefacts, of which some have been built, in various magazines as well as academic research papers and reports.

Karlo FILIPAN (PhD) is a software developer at ASAsense cv, Belgium. He obtained his PhD in 2018 in WAVES Research Group, Ghent University. Previously, he had obtained his MSc Degree in Electrical Engineering and Information Technology from the University of Zagreb, Croatia. During his PhD research, he completed the ITN "Urban sound planner" program in the FP7 project SONORUS. His work focuses on intelligent systems for soundscape investigation and design - including computational modelling, signal processing, machine learning and psychoacoustics.

Barbara GOLIČNIK MARUŠIĆ is head of research at the Urban Planning Institute of the Republic of Slovenia. She holds a PhD in landscape architecture from ECA, Heriot-Watt University, UK (ESALA, University of Edinburgh). She is involved in projects concerned with quality of living and environment-behaviour issues in the context of urban planning and design. She is a member of various international networks, associations and editorial boards. Besides doing research work, she is involved in education: School of Landscape Architecture, ECA, UK (2002-2004), Faculty of Civil Engineering and Architecture, University of Maribor, Slovenia (2008-20I5), visiting lecturer and PhD examiner at different European universities.

Lucas Ariel GOMES holds a master's degree in architecture, technology and the city from the University of Campinas, Brazil, completed with a scholarship granted by CAPES; and a bachelor's degree in architecture and urban studies from the same university. During his bachelor studies, he was an invited visiting student at ETH Zürich and an intern at the Chair of Information Architecture (2012-2013). His academic interests include public spaces, bottom-up processes, housing, urban studies, diversity, the right to the city, parametric and algorithmic tools of analysis in architecture and urban design. His current research addresses the spatiality of everyday collective design.

Laura GUDELYTE் (PhD) is a researcher at Vilnius Gediminas Technical University. Her research focuses on innovation clusters and networked-based collaboration in the context of the knowledge society. Laura is a member of a number of international networks and associations. She is also involved in projects concerned with assessing digital communication in social contexts. 
Konstantinos LALENIS (PhD, M. Eng.) is a professor at the Department of Planning and Regional Development, University of Thessaly, Volos, Greece. His specialization is urban planning and urban governance. He was granted an award for excellence in teaching by AESOP, and another for academic excellence by the Greek Ministry of Education. Current research interests include participation and governance issues, planning law and institutional frameworks, strategic planning, and planning practices.

Sérgio Ricardo LESSA ORTIZ is an architect and urban planner, who graduated from USP/SP and holds a master's degree in performing arts from USP/SP and PhD in performing arts from USP/SP (2020). He is professor and the head of the bachelor's programme in architecture and urban planning of Centro Universitário Belas Artes in São Paulo; he is also partner at SLH Arquitetos Associados.

Filipa LOURENÇO has an academic record in the area of education sciences with a special interest in the fields of interculturality, subaltern knowledges and epistemologies. She has been working as a Science Manager at the Interdisciplinary Research Centre for Education and Development - CeiED at Lusófona University in Lisbon. Currently, she is a PhD student of Intercultural Relations at Universidade Aberta.

Monika MAČIULIENÉ $(\mathrm{PhD})$ is a senior researcher at the Social Technologies LAB (MRU). Her research examines co-creation of value in various contexts. In Mačiulienè's research view, the customer is considered not only a receiver of the end-product, but also a source of innovative solutions and active collaborator, bringing meaningful insights into design and the use of products in businesses, NGOs and public institutions. M. Mačiulienè is part of several international research projects EU-Citizen.Science (H2020), C3Places (H2020) and APPLY COST Action. Individually and together with colleagues, she has prepared over 40 academic publications.

Diogo MATEUS holds a $\mathrm{BA}$, a Master and a PhD in urbanism by Universidade Lusófona, where he is the head of the Master's and $\mathrm{PhD}$ programmes in urbanism. $\mathrm{He}$ is researcher on territorial studies at CeiED - Interdisciplinary Research Centre for Education and Development and has been involved in different research programs funded by national and international agencies, as LUDA (5th FP), Technolangue (Intereg III-MEDOC/MEDA), CyberParks (COST Action) and C3Places (H2020 - JPI Urban Europe). He is also urbanist at Geoideia, where he develops urban and regional plans, territorial studies and analyses. He is a founder of the Portuguese Association of Professional Urbanists. 
Marluci MENEZES is a geographer with a master's degree and a PhD in anthropology from the NOVA University/Lisbon, Portugal, and she is researcher at the National Laboratory of Civil Engineering (LNEC), Lisbon (Portugal). She has been working on a number of national and international research projects covering different issues centred on the relationship between space, society and culture, with several publications related to the studies she has carried out. She is currently studying socio-cultural issues associated with the dynamics of adaptation to urban transformation processes, the relationship between tangible, intangible and digital heritage in the conservation and transmission of cultural heritage. She is member of COST Action TUI306 CyberParks, C3Places, E-RIHS.pt, IPERION CH - Integrated Platform for the European Research Infrastructure on Cultural Heritage, and DB-Heritage (DataBase of building materials with historical and heritage interest PTDC/EPH-PAT/4684/20I4).

Edney MOTA ALMEIDA is a journalist and holds a master's degree and a PhD in social sciences from the Pontifical Catholic University of São Paulo, Brazil. He conducted a doctoral study programme at the Mediation, Information, Communication and Arts Research Lab of the University of Bordeaux, France. He is a researcher at the Centre for Urban Studies and Research and at the Centre for State, Society and Public Policy Studies at the Pontifical Catholic University of São Paulo. Author of the book: Attack and Counter-attack - sports journalism from the perspective of two professional trajectories - Editora Hucitec, 2017.

Catarina PATRÍCIO is a visual artist, researcher at CICANT and Assistant Professor at ECATI University Lusófona. Patrício holds a PhD in Communication Sciences from FCSH-NOVA, and was a FCT post-doctoral fellow at ICNOVA (20 I52020). Patrício holds a MA in Anthropology of Social Movements FCSH-NOVA, and a degree in Painting - Faculty of Fine Arts of Lisbon (FBA-UL, 1998-2003). Catarina Patrício researches and publishes in the field of anthropology of space, philosophy of technics, aesthetics and media theory. https://catarinapatricio.weebly.com.

Silvia Mikami G. PINA is an architect and an associate professor at the University of Campinas, Brazil. She is the leader of the Humanizing the Housing and the City Research Group - CNPq. Her main research topics are housing studies, public space and urban morphology. Her works involve concepts of humanizing in design, urban sustainability, public space appropriation, architecture design methodology and participatory design processes. She was coordinator of the Architecture, Technology and the City Graduate Programme (20I I-20I4) and coordinator of the Architecture and Urban Design Undergraduate Course (2002-2005) at the University of Campinas. 
Filipa RAMALHETE is an anthropologist, with a master's degree and a PhD in Spatial Planning. She lectures at the Department of Architecture of Universidade Autónoma de Lisboa, and is director of the research centre CEACT/UAL, of the journal www.estudoprevio.net and researcher at CICS.Nova. Her main research interests are spatial anthropology, spatial planning, spatial justice and urban studies.

Johannes RIEGLER joined JPI Urban Europe in 2012 where he works as Stakeholder Involvement Officer. As such, he is a mobilising and linking agent between a broad range of actors involved in urban transitions, from grassroots movements, the research community, urban practitioners, urban public administration etc., stimulating them to join discussions, combine and co-create knowledge and translate it into the strategic orientation of the initiative. Johannes holds a B.Sc. in Geography and Regional Science as well as a 4cities MA in Urban Studies. He conducted his studies in Brussels, Vienna, Copenhagen, Madrid, Budapest and Klagenfurt. Johannes is employed by the Austrian Research Promotion Agency FFG.

Agatino RIZZO $(\mathrm{PhD})$ is the chaired professor and head of architecture at Lulea University of Technology, where he leads research and teaching in the broader domain of the built environment. His main interests are the study of the resourceurbanization nexus and how to build resourceful communities. Cross-cutting themes are resilience, climate, landscape, heritage, energy, and transdisciplinary knowledge production. His most recent projects deal with energy aesthetics, participatory methods and urban living labs for nature-based solutions, urban farming, and eco-districts. His research has been funded by the EC research framework programme, Qatar National Research Fund, Vinnova, Formas, and the Swedish Energy Agency.

Tatiana RUCHINSKAYA (PhD, MSt - Cambridge), BA (Hons) Dip Arch) is an internationally trained architect with integrated building design experience, sustainability skills and experience of working in research and teaching environments. She is the founder of JT Environmental Consultants Ltd (UK). She has expertise in city regeneration and sustainable design in the UK and Europe. She completed a few regeneration projects in the UK on her own, and she was part of the design team for well-known public buildings and housing developments across Cambridgeshire.

Débora SANCHES is an architect and urban planner from PUC Campinas (1994), holds a master's degree in housing from IPT of São Paulo, PhD in architecture and urban planning from Universidade Presbiteriana Mackenzie, with a period at LNEC Portugal. She is professor of architecture and urban planning at the Universidade Presbiteriana Mackenzie and lectures in the master's degree programme in architecture, urban planning and design at the Centro Universitário Belas Artes in São Paulo. 
Aelita SKARŽAUSKIENĖ (PhD) is professor and researcher at Vilnius Gediminas Technical University. Her research area is the application of new technologies in different fields of society focusing on innovative management approaches such as distributed leadership and collective intelligence. She has substantial expertise and experience in the preparation and implementation of scientific and study projects. She developed her competencies in internships in the fields of social innovation and technologies at Ajou and EWHA universities in South Korea, USM university in Malaysia, Kasetsart University in Thailand and universities of Kingston, Milano, J. Kepler and Washington.

Carlos SMANIOTTO COSTA (PhD) holds a diploma in landscape architecture and environmental planning and a $\mathrm{PhD}$ in urban and landscape planning from the Leibniz University Hannover/Germany. He lectures landscape design and urban ecology in the master's and $\mathrm{PhD}$ programmes at Lusófona University and is a member of its Interdisciplinary Research Centre for Education and Development, where he leads the research area on urban studies. Smaniotto Costa has been working on a number of national and international research projects covering different issues, all centred on sustainable urban development and transforming cities into more liveable spaces. Smaniotto Costa has published widely on environmental, social and urban geography as well as urban planning and design issues in professional journals in Portuguese, German, English and Italian. $\mathrm{He}$ is one of the initiators and the coordinator of the H2020 JPI UrbanEurope Project C3Places.

Joana SOLIPA BATISTA has a bachelor's degree in International Relations and a master's degree in Social and Cultural Anthropology. She has been working in the C3Places research project at the interdisciplinary Research Centre for Education and Development - CeiED at Lusófona University in Lisbon. She is a PhD student in anthropology at NOVA FSCH / ISCTE-IUL.

Ina ŠUKLJE ERJAVEC (MSc) graduated in landscape architecture (diploma and Master of Science) at the University of Ljubljana. She has a national status of researcher and is a licenced landscape architect and spatial planner. She is senior researcher and project leader of several projects at national and international levels at the Urban Planning Institute. She has comprehensive research experience in theoretical and empirical studies of urban landscape planning and design, as well in developing urban landscape planning and design guidance and methodologies.

Kang SUN holds an MSc degree in Power Mechanical Engineering from Tianjin University (20l4), and a PhD in Engineering Sciences from Ghent University (20I8). During his PhD research, he participated in the Urban Soundscapes of the World project as well as in the EU H2020 Urban Europe project C3Places. He has a wide 
research expertise in acoustics, psychoacoustics and audio-visual interaction, and is co-author of 16 publications in peer-reviewed journals and proceedings of international conferences.

Timothy VAN RENTERGHEM is associate Professor in environmental sound at Ghent University. He obtained a MSc in bioengineering in 1999, and a PhD in Applied Sciences in 2003, both at Ghent University. He was a visiting professor at Sheffield University in 20I4. He has authored nearly 200 publications in journals and conference proceedings. He is a recognized acoustical expert for the Flemish Government, and Associate Editor of Acta Acustica, the journal of the European Acoustical Association, as well as Urban Forestry and Urban Greening.

Lucio Hanai Valeriano VIANA holds a PhD in social sciences from the Pontifical Catholic University of São Paulo, Brazil; a master's degree in public administration and government from the Fundação Getúlio Vargas, São Paulo (2009); a bachelor's in social sciences from PUC-SP (2006). He is Lecturer-Tutor at the IBMEC Group (Damásio Educacional/UniFavip), researcher at the Observatório das Metrópoles São Paulo and at the Centre for State, Society and Public Policy Studies. Reviewer of the journals Direito da Cidade, Íconos e Café com Sociologia. He has large experience in social research and market consultancy.

Caroline WRANGSTEN holds a Master of Science in Human Geography and Environmental Social Studies from Stockholm University. She continuously searchers for meaningful synergy effects and sustainable impact in various urban areas, most recently as co-author to \#UrbanGirlsMovement living labs publications (https:// www.globalutmaning.se/rapporter/), which gained national and international attention in 2019. Before joining JPI Urban Europe, Caroline worked with the sustainable cities program at the independent think tank Global Utmaning and earlier at the United Nation's Association of Sweden. She is alumnus from the Preparing Global Leaders Institute and Höj Rösten Politikerskola - national learning program for innovative changemakers and political talents.

Vita ŽLENDER $(\mathrm{PhD})$ is a landscape architect with a diploma from the University of Ljubljana, Slovenia, and a PhD from the University of Edinburgh, UK. During and after her studies she practiced as a landscape architect in Europe and in the United States, where she gained practical skills in urban and landscape planning. At the same time, she has been active in research, focusing on the problems of sprawled urban development. She has published her findings in different journals and presented them at several conferences. At the UIRS, she has been working in several national and international research projects, including C3Places. 